\title{
НАШИ АВТОРЫ
}

Абдулаев Абдула Магомедович, аспирант Отдела археологии Института истории, археологии и этнографии ДНЦ РАН

Алиев Багомед Гадаевич, главный научный сотрудник Отдела древней и средневековой истории Дагестана Института истории, археологии и этнографии ДНЦ РАН, доктор ист. наук, профессор, Заслуженный деятель науки РД.

Айтберов Тимур Магомедович, исполняющий обязанности старшего научного сотрудника Отдела древней и средневековой истории Дагестана Института истории, археологии и этнографии ДНЦ РАН, кандидат ист. наук.

Гасанов Магомед Раджабович, зав. кафедрой истории Дагестана Даггоспедуниверситета, доктор ист. наук, Заслуженный деятель науки РД и РФ.

Давудов Омар Малаевич, зам. директора Института истории, археологии и этнографии ДНЦ РАН, доктор ист. наук, Заслуженный деятель науки РФ и РД.

Каймаразов Гани Шихвалиевич, главный научный сотрудник Отдела истории Дагестана XIX-XXI вв. Института истории, археологии и этнографии ДНЦ РАН, доктор ист. наук, профессор, Заслуженный деятель науки РД и РФ.

Кидирниязов Даниял Сайдахмедович, ведущий научный сотрудник Отдела истории Дагестана XIX-XXI вв. Института истории, археологии и этнографии ДНЦ РАН, доктор ист. наук, профессор. Заслуженный деятель науки РД.

Курбанов Ханжан Тажидинович, младший научный сотрудник Отдела социологии Института истории, археологии и этнографии ДНЦ РАН, кандадат полит. наук.

Магомедов Юсуп Абдусаламович, аспирант Отдела арехологии Института истории, археологии и этнографии ДНЦ РАН.

Магомедханов Магомедхан Магомедович, зав. Отделом этнографии Института истории, археологии и этнографии ДНЦ РАН, доктор исторических наук.

Мирзабеков Мирзабек Яхьяевич, ведущий научный сотрудник Отдела истории Дагестана XIX-XXI вв. Института истории, археологии и этнографии Дагестанского научного центра РАН, доктор ист. наук, профессор. Заслуженный деятель науки РД.

Мусаев Махач Абдулаевич, зав. Отделом востоковедения Института истории, археологии и этнографии ДНЦ РАН, кандидат ист. наук.

Наврузов Амир Рамазанович, ученый секретарь Института истории, археологии и этнографии ДНЦ РАН, кандидат ист. наук.

Османова Милена Нуриевна, научный сотрудник Института истории, археологии и этнографии ДНЦ РАН, кандидат исторических наук.

Хапизов Шахбан Магомедович, соискатель Отдела этнографии Института истории, археологии и этнографии ДНЦ РАН.

Шехмагомедов Магомед Гаджиевич, младший научный сотрудник Отдела востоковедения Института истории, археологии и этнографии ДНЦ РАН. 
Шихсаидов Амри Рзаевич, главный научный сотрудник Отдела востоковедения Института истории, археологии и этнографии ДНЦ РАН, доктор ист. наук, профессор, Заслуженный деятель науки РФ и РД. 


\section{OUR AUTHORS}

Abdulaev Abdula Magomedovich, post- graduate student, Department of Archaeology, Institute of History, Archaeology and Ethnography (IHAE), the Dagestan Scientific Centre (DSC), the Russian Academy of Sciences (RAS)

Aliev Bagomed Gadaevich, chief researcher, Department of the Ancient and Medieval History of Dagestan, IHAE DSC RAS, Doctor of History, professor, Honoured Scientist of the Republic of Dagestan.

Aytberov Timur Magomedovich, acting senior researcher, Department of the Ancient and Medieval History of Dagestan, IHAE DSC RAS, Candidate of History.

Gasanov Magomed Radzhabovich, head of the chair of History of Dagestan, the Dagestan State Pedagogical University, Doctor of History, Honoured Scientist of the Republic of Dagestan and the Russian Federation.

Davudov Omar Malaevich, deputy director, IHAE DSC RAS, Doctor of History, professor, Honoured Scientist of the Republic of Dagestan and the Russian Federation.

Kaymarazov Gani Shikhvalievich, chief researcher, Department of the Dagestan History of the $19^{\text {th }}-21$ st cc., Doctor of History, professor, Honoured Scientist of the Republic of Dagestan and the Russian Federation.

Kidirniyazov Daniyal Saidahmedovich, leading researcher, Department of the Dagestan History of the 19th-21st cc., IHAE DSC RAS, Doctor of History, professor, Honoured Scientist of the Republic of Dagestan.

Kurbanov Khanzhan Tazhidinovich, junior researcher, Department of Sociology, IHAE DSC RAS, Candidate of Political Science.

Magomedov Yusup Abdusalamovich, post-graduate student, Department of Archaeology, IHAE DSC RAS.

Magomedkhanov Magomedkhan Magomedovich, head of the Department of Ethnography, IHAE DSC RAS, Doctor of History.

Mirzabekov Mirzabek Yakhiyaevich, leading researcher, Department of the Dagestan History of the 19th-21st cc., IHAE DSC RAS, Doctor of History, professor, Honoured Scientist of the Republic of Dagestan.

Musaev Makhach Abdulaevich, head of the Department of Oriental Studies, IHAE DSC RAS, Candidate of History.

Navruzov Amir Ramazanovich, scientific secretary, IHAE DSC RAS, Candidate of History.

Osmanova Milena Nurievna, researcher, IHAE DSC RAS, Candidate of History.

Khapizov Shakhban Magomedovich, applicant, Department of Ethnography, IHAE DSC RAS, Candidate of History.

Shekhmagomedov Magomed Gadzhievich, junior researcher, Department of Oriental Studies, IHAE DSC RAS. 
Shikhsaidov Amri Rzaevich, chief researcher, Department of Oriental Studies, IHAE DSC RAS, Doctor of History, professor, Honoured Scientist of the Republic of Dagestan and the Russian Federation. 